\title{
Predation and physical disturbance by crabs reduce the relative impacts of nutrients in a tidal mudflat
}

\author{
Anna R. Armitage ${ }^{1,2, *}$, Peggy Fong ${ }^{1}$ \\ ${ }^{1}$ University of California Los Angeles, Department of Ecology and Evolutionary Biology, 621 Charles E. Young Drive South, \\ Los Angeles, California 90095-1606, USA \\ ${ }^{2}$ Present address: Florida International University, Southeast Environmental Research Center-OE 148, 11200 SW 8th Street, \\ Miami, Florida 33199, USA
}

\begin{abstract}
We evaluated how links between direct and indirect interactions and physical disturbance shaped trophic dynamics in a soft-sediment benthic estuarine community. We crossed presence of burrow-excavating crabs Pachygrapsus crassipes and nutrient enrichment (nitrogen and phosphorus) in cages containing herbivorous surface-feeding snails Cerithidea californica and benthic microalgae in a tidal mudflat and a tidal sandflat in Mugu Lagoon, southern California, USA. $P$. crassipes consumed up to $85 \%$ of $C$. californica in enclosures, but there was no evidence of a trophic cascade, as crab reduction of snail density did not increase benthic microalgal biomass. Rather, $P$. crassipes decreased diatom and cyanobacterial biomass by up to $50 \%$ in the mudflat and $80 \%$ in the sandflat, probably via bioturbation. Subadult C. californica lengths increased 15 to $20 \%$ over 5 wk in treatments without crabs. In the presence of $P$. crassipes, $C$. californica lengths increased $<5 \%$, probably an indirect result of crab reduction of microalgal food availability or increased snail burial. $C$. californica may have actively burrowed as an escape response from the crabs, or have been passively buried during crab burrowing activities. Nutrient addition did not reduce snail growth, but increased snail mortality at both sites, possibly a result of nutrient-induced shifts towards toxic or poor nutritive quality cyanobacteria. The top-down impacts of $P$. crassipes reduced the relative bottom-up effects of nutrients in this habitat, illustrating the importance of evaluating both biotic and abiotic interactions simultaneously. Numerous indirect and non-trophic interactions revealed a community structure that was much more complex than suggested by food web structure.
\end{abstract}

KEY WORDS: Bioturbation · Epifauna - Indirect interactions · Microphytobenthos · Nutrients · Sediment · Trophic dynamics

Resale or republication not permitted without written consent of the publisher

\section{INTRODUCTION}

Numerous complex direct and indirect interactions act in concert to shape communities. Predation can be a strong direct structuring force, altering prey density, fitness, and species composition (Paine 1974, Blumenshine et al. 2000). Nutrient enrichment can have similarly potent impacts by increasing food supply for upper trophic levels (Widbom \& Elmgren 1988), or facilitating blooms of opportunistic, weedy, or toxic species (Valiela et al. 1997). Direct impacts of predators and nutrients are sometimes independent of each other (Wiltse et al. 1984, Posey et al. 1999, Heck et al.
2000), but the strengths of those top-down and bottomup forces are frequently altered through indirect pathways (Menge 1995, Thrush 1999). Indirect effects often involve the impact of one species on another by way of a direct interaction with a third species (Menge 1995). Trophic cascades are a well-documented example, in which predation on a herbivore indirectly increases primary producer biomass (e.g. Carpenter et al. 1985). Indirect interactions may also follow non-trophic pathways, such as disturbance of other trophic levels during foraging activities (Palmer 1988, Thrush 1999), or trait-mediated indirect interactions, including alterations of prey behavior in the presence of predators 
(Schmitz et al. 1997). The complexity of these types of direct and indirect interactions within communities is re-defining food webs and the rules of community assembly (Menge 1995).

The combined influences of both direct and indirect interactions on marine communities have been examined in aquatic, pelagic, and rocky intertidal habitats, but much less is known about their importance in the soft-sediment benthic habitats that are important components of coastal lagoon and estuarine ecosystems (Menge 1995, Liess \& Hillebrand 2004). Grazers and nutrients can have indirect impacts on the benthic microalgal community through alterations of species composition and diversity (Hagerthey et al. 2002, Armitage \& Fong 2004b), but few studies have investigated the direct and indirect roles of predators in these systems (Liess \& Hillebrand 2004). Direct effects of predation on soft-sediment infaunal communities are sometimes weak (Ólafsson et al. 1994), suggesting that complex indirect interactions may be masking direct trophic effects in these habitats (Thrush 1999). Mechanisms for predator-mediated indirect interactions include disturbance of non-prey organisms during foraging activities (Palmer 1988, Thrush 1999) or consumption of superior competitors or predators (Ambrose 1984, Bonsdorff et al. 1995, Hamilton 2000). The few studies that have experimentally addressed the relative importance of direct and indirect interactions on soft-sediment communities suggest that indirect predator effects may be as or more important than direct effects (Ambrose 1984, Palmer 1988). There is also some evidence that direct effects (predation) and indirect effects (disturbance) may act synergistically (Bonsdorff et al. 1995), though most of these studies focus on predation on infaunal communities. The importance of epifauna as ecosystem engineers in softsediment systems has been well established (Bertness 1985, Commito et al. 2005), but experimental studies of the relative importance of both top-down and bottomup direct and indirect effects of predators in these habitats are lacking (Liess \& Hillebrand 2004), particularly on the west coast of the USA.

We explored the relative importance of direct and indirect impacts of a burrow-excavating, predatory crab and nutrient enrichment on a benthic estuarine community. Previous work in this system revealed numerous indirect interactions among herbivorous mud snails, benthic microalgae, and nutrients, whereby nutrient addition indirectly impacted the snails by increasing cyanobacterial abundance, which subsequently increased snail mortality 3 -fold (Armitage \& Fong 2004b). The dramatic alterations of community structure in this system due to nutrient addition suggested that the impacts of the predatory crabs might vary under different nutrient-enrichment regimes. We predicted that crabs would directly affect grazing snails through consumption and that crabs would have indirect effects on snail survival by reducing microalgal abundance through burrowing activities.

\section{MATERIALS AND METHODS}

Study system. We performed the following studies in 2 tidal flats with sediment ranging from $8 \%$ mud (grains $<62 \mu \mathrm{m}$ diameter) content (referred to as the sandflat) to $29 \%$ mud content (referred to as the mudflat) in Mugu Lagoon, southern California, USA $\left(34.11^{\circ} \mathrm{N}, 119.12^{\circ} \mathrm{W}\right)$.

The predator in this system, the shore crab Pachygrapsus crassipes Randall (adult carapace width 30 to $40 \mathrm{~mm}$ ), disturbs surficial sediment through excavation of shallow burrows and consumes a variety of salt marsh fauna (Hiatt 1948). The epibenthic gastropod Cerithidea californica Haldeman (California horn snail, adult length 20 to $30 \mathrm{~mm}$ ) is a frequent component of its diet (Sousa 1993). C. californica, in turn, consumes benthic microalgae (Whitlatch \& Obrebski 1980), which in this region consists mainly of diatoms and cyanobacteria (Armitage \& Fong 2004b).

Test for cage effects. We performed a study in August 2001 to test cage design and determine the extent of cage effects on sediment properties. In both the mudflat and the sandflat, we installed ten $0.5 \times$ $0.5 \mathrm{~m}$ enclosures constructed from fiberglass window screening (1.6 mm mesh). Walls of the enclosures extended $20 \mathrm{~cm}$ above and $5 \mathrm{~cm}$ below the sediment to minimize animal immigration and emigration. Enclosure lids were made from window screening and attached with clothespins. In each site, we also installed 5 'lid only' structures, consisting of screen lids held up with bamboo stakes to simulate the shading effects of the cages. In addition, we established 5 open plots per site. Crabs Pachygrapsus crassipes were initially removed from all 10 enclosures; ambient snail Cerithidea californica densities $\left(\sim 200 \mathrm{~m}^{-2}\right)$ remained in each treatment. Of the 10 complete enclosures, 5 were randomly designated as '-crab' treatments. Ambient densities of crabs were added to the other 5 enclosures, and these were designated as '+crab' treatments. From tidal creeks in adjacent marsh areas we collected $P$. crassipes large enough (carapace width $32 \mathrm{~mm}$ ) to consume C. californica up to $25 \mathrm{~mm}$ in length (Sousa 1993). We haphazardly assigned 4 crabs to each of the +crab enclosures, approximating local summer crab densities (A. R. Armitage unpubl. data).

After $5 \mathrm{wk}$, we collected cores to determine if the enclosures altered the physical or biological characteristics of the sediment. We pooled 8 sediment cores ( $2 \mathrm{~cm}$ deep, $2.5 \mathrm{~cm}$ diameter) from each plot and de- 
termined percentage mud content using the hydrometer fractionation method of Bouyoucos (1962), sediment organic content as loss on ignition after $10 \mathrm{~h}$ at $400^{\circ} \mathrm{C}$ and water content as weight loss after drying at $60^{\circ} \mathrm{C}$ for $48 \mathrm{~h}$. To estimate total benthic microalgal biomass, we collected 3 randomly located cores from each plot ( $3 \mathrm{~mm}$ deep, $1.5 \mathrm{~cm}$ diameter), transported them on ice in a dark cooler, and froze them at $-20^{\circ} \mathrm{C}$ until analysis. We extracted pigments with $90 \%$ acetone and determined chlorophyll a concentration using the spectrophotometric method of Lorenzen (1967). Homoscedasticity of all variances was verified using the $F_{\max }$ test, and transformation of the data was unnecessary. Data were analyzed with 1-way ANOVA (analysis of variance) within each site; the factor was cage treatment.

Test of interactive effects. To evaluate the roles of direct and indirect trophic interactions, non-trophic interactions, and modifications of habitat characteristics on community structure, we conducted a 2 -factor experiment varying predator presence (plus or minus crabs) and nutrient supply (plus or minus nutrients) in May 2002. In both the mudflat and the sandflat, we installed twenty $0.5 \times 0.5 \mathrm{~m}$ enclosures as described above. All Cerithidea californica and Pachygrapsus crassipes present in the enclosures following installation were removed.

We augmented development of the microalgal community by adding nutrients to 10 randomly assigned enclosures at each site. A window-screen mesh bag containing $10 \mathrm{~g}$ of slow-release Osmocote fertilizer $(18 \%$ nitrogen $[\mathrm{N}]$ and $12 \%$ phosphorus $[\mathrm{P}]$ by dry weight) was secured to the center of all +nutrient enclosures; empty screen bags were placed in cages with ambient nutrient (-nutrient) treatments. Biweekly additions of $2 \mathrm{~g}$ of granulated urea fertilizer ( $46 \% \mathrm{~N}$ by dry weight) supplemented the Osmocote addition. This protocol was known to increase microalgal biomass and induce cyanobacterial growth by the end of the 3 wk pre-experiment period (Armitage \& Fong 2004b). We randomly selected $5+$ nutrient and 5 -nutrient plots to contain ambient crab density (+crab) enclosures at each site. We collected Pachygrapsus crassipes as above and haphazardly assigned 4 crabs to each of the + crab enclosures. No crabs were added to the other 10 cages at each site (-crab).

We collected Cerithidea californica from an adjacent mudflat and individually numbered them using tags printed on Nalgene waterproof paper, attached with Krazy Glue, and lacquered with clear nail polish. Shell lengths were measured to the nearest $0.05 \mathrm{~mm}$ with calipers and divided into 2 size classes: 15 to $20 \mathrm{~mm}$ (approximately corresponding to juvenile and subadult snails) and 20.05 to $25 \mathrm{~mm}$ (adults). Snails outside these size classes were less common and not included in this study. Twenty-two C. californica from each size class were randomly assigned to each experimental cage to approximate natural densities (Armitage \& Fong 2004a) and were placed in the cages $5 \mathrm{~d}$ after Pachygrapsus crassipes addition, initiating a $5 \mathrm{wk}$ experimental period.

We determined Cerithidea californica mortality and burial of live snails to assess the direct and indirect trophic effects of Pachygrapsus crassipes predation and nutrient enrichment. C. californica consume benthic microalgae on the sediment surface (Whitlatch \& Obrebski 1980), but may burrow into the sediment as an escape response (McCarthy \& Fisher 2000). Thus, to assess indirect effects of $P$. crassipes on $C$. californica foraging behavior, we counted all snails visible on the sediment surface at the conclusion of the 5 wk experimental period. We then collected all snails by sifting the top $3 \mathrm{~cm}$ of sediment from each enclosure through a $1 \mathrm{~mm}$ sieve. We counted the total number of surviving snails in each plot in both size classes and calculated snail burial as a percentage of the live snails in each plot that were not on the sediment surface. In addition, 2 sources of mortality were assessed. P. crassipes crushes shells into many small pieces to consume them (Sousa 1993), so recovery of marked broken shells indicated crab predation. Other, non-predation sources of mortality were determined by the absence of an operculum, or by black or white bacterial films on the mouth of the shell (Byers 2000). Predation mortality and non-predation mortality are reported as percentages of the total number of snails originally placed in the plot. Based on the number of live and dead snails collected, we then calculated the percentage of missing snails. Complete pulverization of the shells may have occurred during consumption, suggesting that many of the missing $C$. californica were probably ingested by $P$. crassipes as well. The homoscedasticity of all variances was confirmed using the $F_{\max }$ test, and data were log transformed if necessary to conform to the assumptions of ANOVA. We analyzed percentage of buried snails with 2-way ANOVA within each site; the factors were plus or minus nutrients and plus or minus crabs. We also analyzed percentage mortality from crab predation with 2-way ANOVA within each site; the factors were plus or minus nutrients and initial snail size class (crab treatment was not included as a factor because no predation by crabs occurred in plots without crabs). The percentage of non-predation mortality and the percentage of missing snails were analyzed with 3-way ANOVA; the additional factor was plus or minus crabs.

To evaluate direct and indirect effects of crabs and nutrients on snail growth, we re-measured all intact snails at the end of the experimental period and used the average per-plot percentage growth in each initial snail size class as the response variable. The homo- 
scedasticity of variances was confirmed using the $F_{\max }$ test, and data were log transformed if necessary to conform to the assumptions of ANOVA. Small-snail growth rates were analyzed with 2-way ANOVA within each site; the factors were plus or minus nutrients and plus or minus crabs. Living large snails were not recovered from all plots in the sandflat, resulting in insufficient replication for ANOVA ( $\mathrm{n} \leq 2)$, so largesnail growth rates are reported as means $( \pm \mathrm{SE})$ for that site. Large-snail growth rates in the mudflat were analyzed as for small snails.

To quantify the direct effects of nutrient enrichment and the non-trophic effects of Pachygrapsus crassipes (e.g. bioturbation) on the benthic microalgal community, we estimated the biomass of the 2 dominant microalgal groups, diatoms and cyanobacteria, in the experimental cages at the end of the $5 \mathrm{wk}$ study period. From each plot, we pooled 3 randomly located cores of $1.5 \mathrm{~cm}$ diameter and a depth $(3 \mathrm{~mm})$ sufficient to encompass the bulk of the microphytobenthic biomass (Wiltshire 2000). Cores were transported to the laboratory on ice in a dark cooler and frozen at $-20^{\circ} \mathrm{C}$ until analysis. We extracted pigments with $90 \%$ acetone and determined the concentration of chlorophyll a to estimate total microphytobenthic biomass and the concentrations of the pigments characteristic of the 2 major microalgal groups (fucoxanthin [diatom] and zeaxanthin [cyanobacteria]) according to the high-performance liquid chromatography method of Brotas \& Plante-Cuny (1996). The homoscedasticity of variances was confirmed using the $F_{\text {max }}$ test, and data were log transformed if necessary to conform to the assumptions of ANOVA. Pigment concentrations were analyzed with 2-way ANOVA within each site; the factors were plus or minus nutrients and plus or minus crabs.

\section{RESULTS}

\section{Test for cage effects}

None of the sediment characteristics we measured were affected by cage treatment (1-way ANOVA, all p > 0.1), suggesting minimal cage effects on the sediment and microalgae. There were several differences in sediment characteristics between sites. Mud content was higher in the mudflat (mean $\pm \mathrm{SE}: 28.8 \pm 2.0 \%$ ) than in the sandflat $(8.2 \pm 0.5 \%)$. Sediment organic content was higher in the mudflat $(8.3 \pm 0.6 \%)$ than in the sandflat $(2.2 \pm 0.2 \%)$, as was sediment water content (mudflat: $63.7 \pm 2.9 \%$; sandflat: $33.7 \pm$ $1.6 \%$ ). Benthic chlorophyll a concentration was similar between sites (mudflat: $482.5 \pm 34.9 \mathrm{mg} \mathrm{m}^{-2}$; sandflat: $432.4 \pm 42.0 \mathrm{mg} \mathrm{m}^{-2}$ ).

\section{Test of interactive effects}

Snail mortality from non-predation sources was strongly influenced by nutrient addition, as it occurred almost exclusively in +nutrient treatments in both the mudflat (df $=1, F=9.922, \mathrm{p}=0.0035$ ) and the sandflat (df $=1, F=20.775, \mathrm{p}<0.0001$; Fig. 1a,b). Crabs or initial size class did not affect this type of mortality, with no interactions between factors (all $\mathrm{p}>0.05$ ). Overall, non-predation mortality was similar between sites.
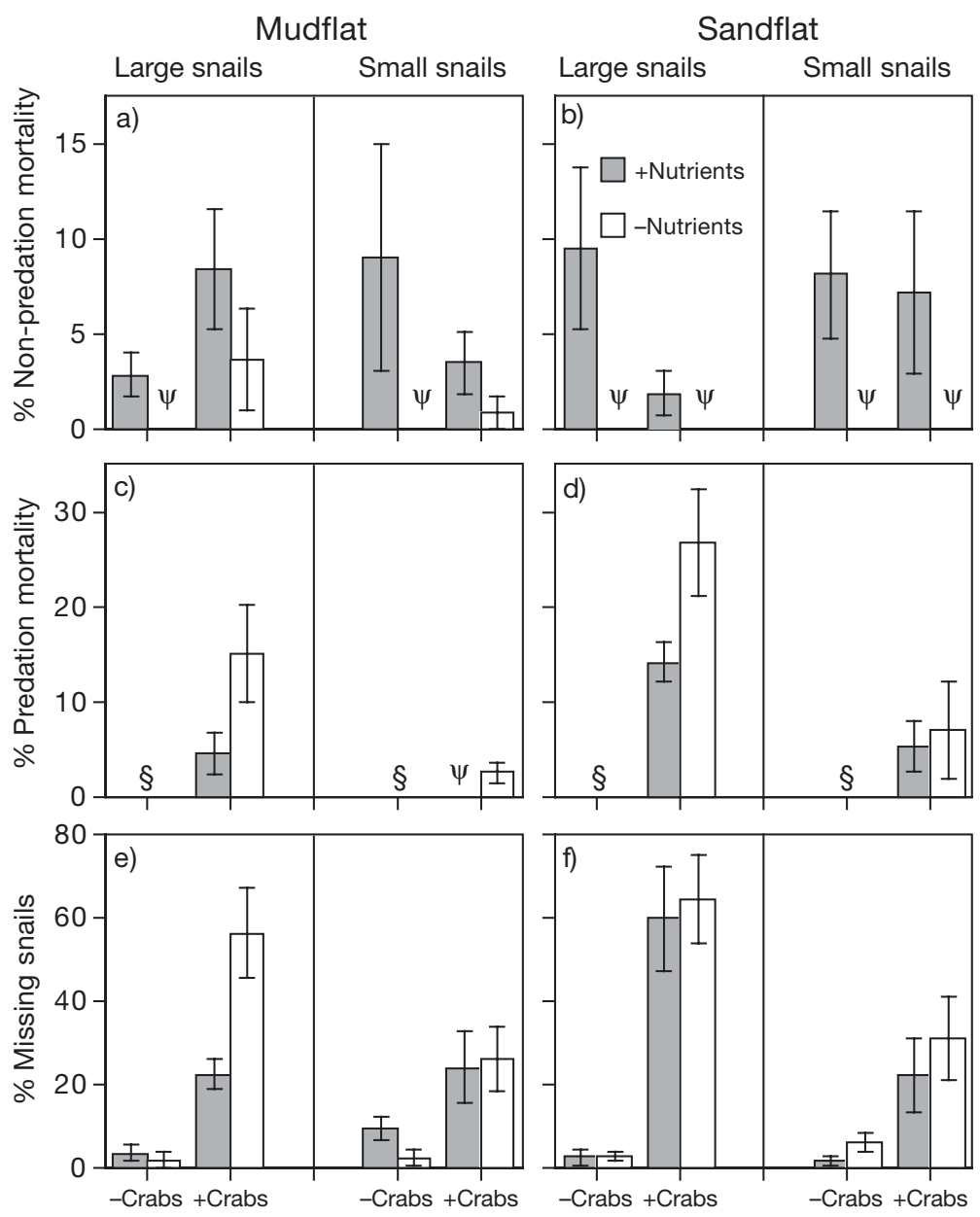

Fig. 1. Pachygrapsus crassipes and Cerithidea californica. Effects of crabs, nutrients, and initial snail size on $(a, b)$ snail mortality from non-predation sources, $(c, d)$ snail mortality from crab predation, and $(e, f)$ percentage of missing snails on a tidal mudflat and on a sandflat. Error bars are SE ( $§$ : not applicable; $\psi$ : no mortality detected) 
Snail mortality from crab predation was significantly higher for large than for small snails at both sites (mudflat: $\mathrm{df}=1, F=5.662, \mathrm{p}=0.0301$; sandflat: $\mathrm{df}=1, F=$ 14.838, $p=0.0014$; Fig. 1c,d), with no interactions between factors. In the mudflat, nutrient enrichment lowered percentage predation mortality ( $\mathrm{df}=1, F=$ 9.724, $\mathrm{p}=0.0066$ ). There was a trend of decreased crab predation on large snails in enriched treatments in the sandflat as well, though the nutrient effect was not significant due to high variability between nutrient treatments for small snails. Predation on snails appeared to be more intense in the sandflat than in the mudflat.

Generally, $>90 \%$ of the snails were recovered from plots without crabs, but there were complex treatment effects on the number of missing snails. In the mudflat, there was a significant interaction between crab and nutrient effects on the percentage of missing snails due to more missing large snails in -nutrient plots when crabs were present and more missing small snails in +nutrient plots when crabs were absent (Fig. 1e, Table 1). In the sandflat, there was a significant interaction between crabs and initial snail size class on the percentage of missing snails (Table 1). This interaction stemmed from more missing snails in plots with crabs than without crabs, but this effect was stronger for large snails (Fig. 1f).

A significantly higher percentage of the surviving snails was buried in plots with crabs than in plots without crabs at both sites (mudflat: $\mathrm{df}=1, F=17.816, \mathrm{p}=$ 0.0006; sandflat: $\mathrm{df}=1, F=36.761, \mathrm{p}<0.0001$; Fig. 2).

Table 1. Pachygrapsus crassipes and Cerithidea californica. Results of 3-way ANOVA of crabs, nutrients, and size class on the percentage of snails missing from plots on a tidal mudflat and a tidal sandflat

\begin{tabular}{|lcrrr|}
\hline & df & MS & $F$ & \multicolumn{1}{c|}{$p$} \\
\hline Mudflat & & & & \\
Crabs (C) & 1 & 8.74 & 54.16 & $<0.0001$ \\
Nutrients (N) & 1 & 0.10 & 0.62 & 0.4359 \\
Initial size (S) & 1 & 0.01 & 0.05 & 0.8245 \\
$\mathrm{C} \times \mathrm{N}$ & 1 & 1.017 & 6.30 & 0.0173 \\
$\mathrm{C} \times \mathrm{S}$ & 1 & 0.52 & 3.22 & 0.0820 \\
$\mathrm{~N} \times \mathrm{S}$ & 1 & 0.16 & 1.00 & 0.3241 \\
$\mathrm{C} \times \mathrm{N} \times \mathrm{S}$ & 1 & $<0.01$ & 0.01 & 0.9256 \\
Residual & 32 & 0.16 & & \\
& & & & \\
Sandflat & & & & \\
$\mathrm{Crabs}(\mathrm{C})$ & 1 & 10.22 & 43.26 & $<0.0001$ \\
Nutrients (N) & 1 & 0.36 & 1.51 & 0.2282 \\
Initial size (S) & 1 & 0.51 & 2.17 & 0.1502 \\
$\mathrm{C} \times \mathrm{N}$ & 1 & 0.06 & 0.26 & 0.6150 \\
$\mathrm{C} \times \mathrm{S}$ & 1 & 1.14 & 4.84 & 0.0352 \\
$\mathrm{~N} \times \mathrm{S}$ & 1 & 0.12 & 0.49 & 0.4905 \\
$\mathrm{C} \times \mathrm{N} \times \mathrm{S}$ & 1 & 0.04 & 0.17 & 0.6837 \\
Residual & 32 & 0.24 & & \\
\hline
\end{tabular}

Nutrients did not affect snail burial, and there were no interactions between factors (all $\mathrm{p}>0.1$ ). Overall, the percentage of buried snails was similar between sites.

At both sites, small snail growth was high (15 to $20 \%$ increase in snail length) in plots without crabs, but was reduced by $>50 \%$ in plots with crabs (mudflat: $\mathrm{df}=1$, $F=30.700, \mathrm{p}<0.0001$; sandflat: $\mathrm{df}=1, F=24.475, \mathrm{p}=$ 0.0002; Fig. 3). Nutrients did not affect small snail growth rates at either site, and there were no interactions between factors (all $\mathrm{p}>0.1$ ). In the mudflat, large snail growth was low ( 2 to $5 \%$ increase in snail length) in plots without crabs, but was reduced to 0 in plots with crabs ( $\mathrm{df}=1, F=26.072, \mathrm{p}=0.0001)$. A similar trend occurred in the sandflat, though statistical comparisons were not made because live large snails were not recovered from all +crab plots in the sandflat (n $\leq 2)$. In the mudflat, nutrients did not affect large snail growth rates, and there were no interactions between factors at either site (all $\mathrm{p}>0.1$ ).

At the end of the experimental period, the benthic chlorophyll a concentration was lower in the presence of crabs at both sites (mudflat: $\mathrm{df}=1, F=4.603, \mathrm{p}=$ 0.0476; sandflat: $\mathrm{df}=1, F=31.201, \mathrm{p}<0.0001$ ), but was unaffected by nutrients, with no interactions between factors (all p > 0.05) (Fig. 4a,b). Benthic fucoxanthin

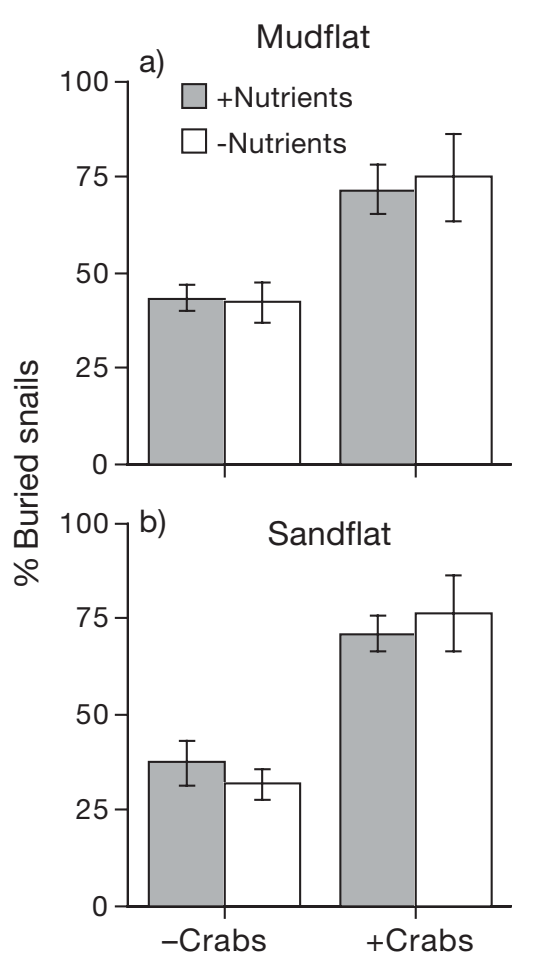

Fig. 2. Pachygrapsus crassipes and Cerithidea californica. Effects of crabs and nutrients on the percentage of surviving snails that were buried at the end of the 5 wk study period on (a) a tidal mudflat and (b) a tidal sandflat. Error bars are SE 


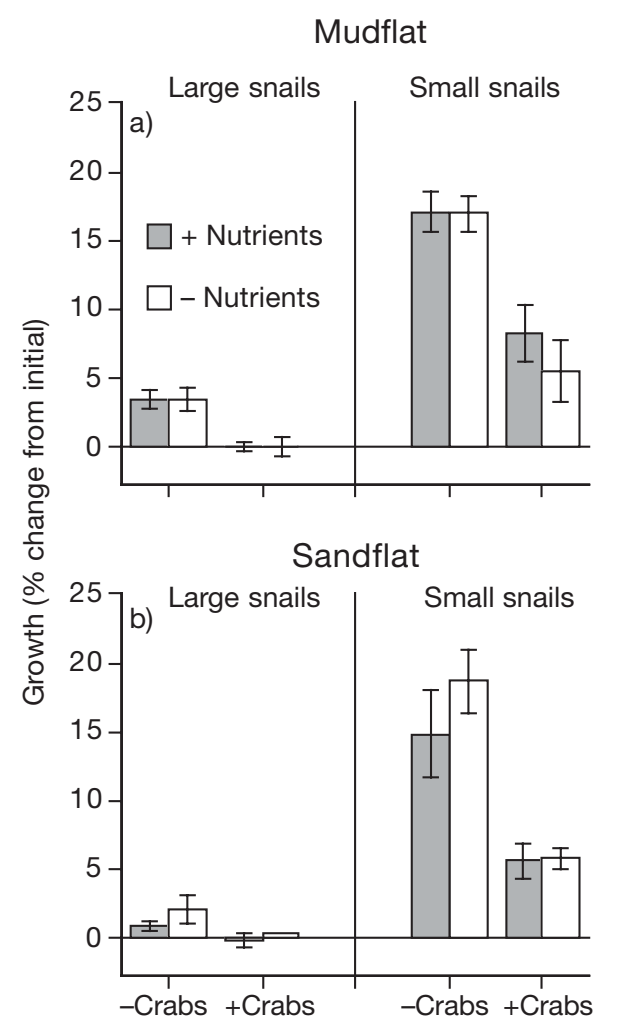

Fig. 3. Pachygrapsus crassipes and Cerithidea californica. Percentage change in length of small (15 to $20 \mathrm{~mm}$ initial length) and large (20 to $25 \mathrm{~mm}$ ) snails over the $5 \mathrm{wk}$ study period in response to crabs and nutrients on (a) a tidal mudflat and (b) a tidal sandflat. Error bars are SE

(diatom) concentration was also lower in the presence of crabs at both sites (mudflat: $\mathrm{df}=1, F=7.666, \mathrm{p}=$ 0.0137; sandflat: $\mathrm{df}=1, F=39.209, \mathrm{p}<0.0001$; Fig. $4 \mathrm{c}, \mathrm{d}$ ), with no nutrient effects or interactions between factors (all $\mathrm{p}>0.05$ ). Benthic zeaxanthin (cyanobacteria) concentration was lower in the presence of crabs, but only in the sandflat ( $\mathrm{df}=1, F=$ 13.860, $\mathrm{p}=0.0019$; mudflat: $\mathrm{p}>0.1$; Fig. 4e,f), with no nutrient effects or interactions between factors. Overall, all pigment concentrations were lower in the mudflat than in the sandflat.

\section{DISCUSSION}

The combined forces of direct and indirect interactions are important drivers shaping community structure in terrestrial and marine ecosystems (Menge 1995, Hobbs 1996), but they remain poorly understood in the soft-sediment marine habitats that are widespread in coastal wetlands and estuaries (Liess \& Hillebrand 2004). Our study explored these dynamics in softsediment communities and detected closely coupled
Mudflat
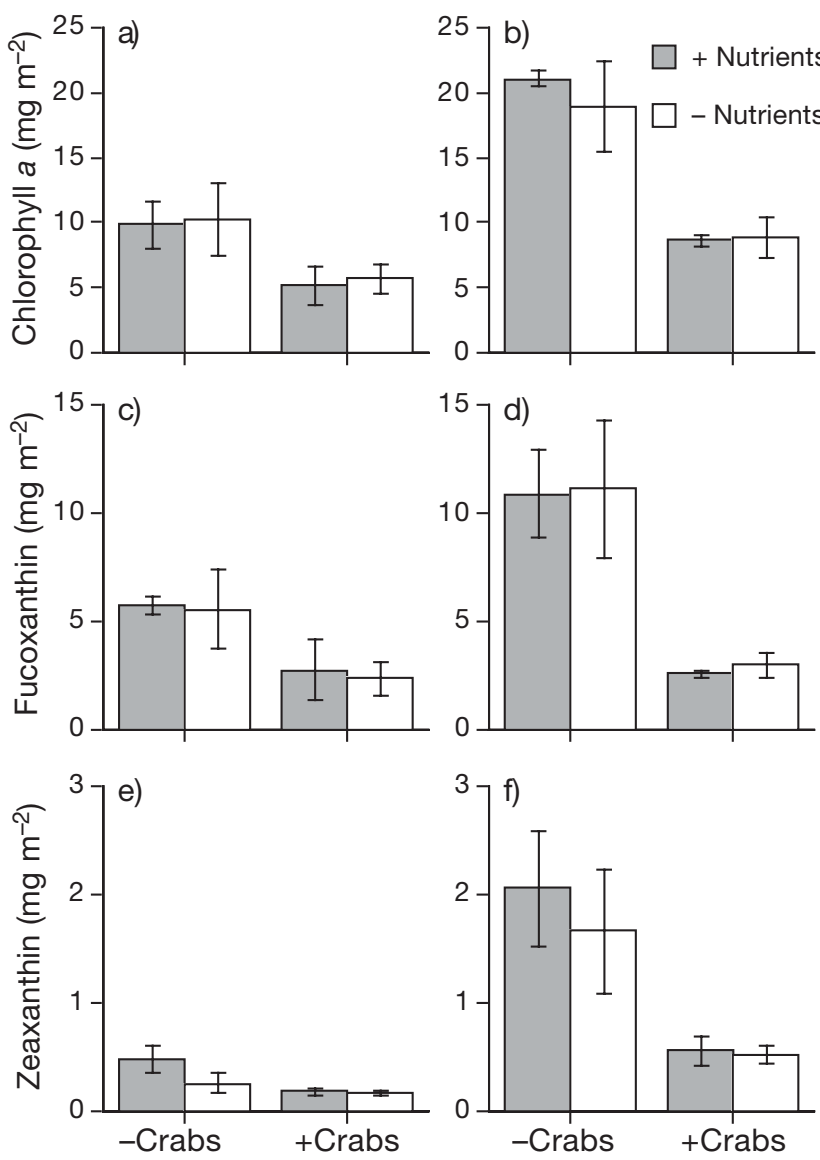

Fig. 4. Pachygrapsus crassipes. Effects of crabs and nutrients on the benthic microalgal community from a tidal mudflat and a tidal sandflat. Effect on $(a, b)$ chlorophyll a (total microalgal biomass), (c,d) fucoxanthin (diatom biomass), and (e,f) zeaxanthin (cyanobacterial biomass). Error bars are SE

direct and indirect interactions among predators, grazing epifauna, and microalgae. In addition to consumption of Cerithidea californica, Pachygrapsus crassipes exerted strong indirect impacts on the benthic community through sediment and microalgal disturbance and modifications of snail foraging activities. Evidence for the prevalence of indirect predator effects has been documented in a wide variety of habitats, including tide pool communities (Trussell et al. 2004), grassland arthropod communities (Schmitz et al. 1997), and temperate pond assemblages (Peacor \& Werner 1997). Previous work in soft-sediment communities has focused on indirect trophic interactions like trophic cascades (Liess \& Hillebrand 2004) and the roles of habitat modifications on trophic dynamics (Rhoads \& Young 1970). Ecosystem engineers have important indirect effects on benthic communities by altering sediment characteristics and structural complexity (Bertness 1985, 
Boyer \& Fong 2005, Commito et al. 2005), but we illustrated a different range of non-trophic, indirect effects of predators on a soft-sediment marine habitat.

We observed few links between direct top-down (predation) and bottom-up (nutrient enrichment) trophic forces in this study. The effects of nutrient and crab addition on the microalgal and snail assemblages were largely independent of each other, though nutrients may have slightly decreased crab fitness or activity, as predation-related mortality of snails was lower in nutrient-addition treatments. Omnivory can decouple top-down and bottom-up forces, as documented in seagrass beds in the Gulf of Mexico (Heck et al. 2000) and freshwater wetlands in Florida (Geddes \& Trexler 2003). This mechanism may have been important in our study, as Pachygrapsus crassipes are often omnivorous, consuming infauna and macroalgae in addition to gastropods (Hiatt 1948, Boyer \& Fong 2005). Interactions between top-down and bottom-up forces may also be decoupled if direct predation effects are extremely strong (Posey et al. 1999). P. crassipes crush shells into small pieces to consume them (Sousa 1993), so many of the missing Cerithidea californica were probably ingested by $P$. crassipes, suggesting that crabs may have consumed as many as 70 to $85 \%$ of the large snails. Strong predation impacts have also been documented in soft-sediment communities on the east coast of the USA (Posey et al. 1999, Hunt \& Mullineaux 2002). Although the predation intensity we observed may have been somewhat inflated by enclosing the predators in cages with the prey, non-predation mortality, which was most likely due to nutrient addition, was very low relative to predation mortality, suggesting that predators decreased the relative importance of nutrient addition for the snails. This concurs with studies of the east coast of the United States demonstrating that predation is often an important, though temporally variable, structuring force in soft-bottom communities that may overwhelm bottom-up effects of nutrient enrichment (Wiltse et al. 1984). Temporal variability in predation forces may have reduced the effectiveness of our test for cage effects, which was performed in August, when compared to the test for interactive effects, which was performed in May. However, $P$. crassipes tend to be abundant and active throughout the summer months (Quammen 1984), suggesting that crab impacts on the snails, microalgae, and sediment were relatively consistent during this period.

Though there were few links between direct topdown and bottom-up interactions in our study system, both nutrients and Pachygrapsus crassipes had many indirect effects on other community components. Nutrient addition did not increase cyanobacterial biomass as we expected based on previous tidal flat studies (Pinckney et al. 1995, Armitage \& Fong 2004b).
Grazing can suppress microalgal biomass under varying levels of productivity (Kaehler \& Froneman 2002). Measurement of microalgal productivity would have clarified whether the minimal microalgal responses to nutrient enrichment that we observed were due to grazer regulation. However, shifts in cyanobacterial species composition also commonly occur in response to enrichment (Kuffner \& Paul 2001), even if total biomass remains unchanged. A shift towards toxic or lower nutritive value species (Ferrão-Filho et al. 2000) provides a likely explanation for increased Cerithidea californica mortality in enriched plots. This is supported by previous experimental work in this region that strongly suggests that diet composition is responsible for nutrient-related $C$. californica mortality (Armitage \& Fong 2004b). Crabs may have also been indirectly affected by nutrient addition, as $P$. crassipes can consume benthic microalgae (Hiatt 1948). We observed few qualitative treatment responses by $P$. crassipes in this short-term study, but negative effects of nutrient addition on $P$. crassipes are suggested by lower snail mortality from crab predation in the enriched treatments.

Despite Pachygrapsus crassipes predation on Cerithidea californica, there was no evidence of a trophic cascade, where benthic algae proliferate following a release from herbivore pressure. Rather, benthic microalgal biomass (as indicated by chlorophyll a concentration) was markedly lower in plots with crabs. $P$. crassipes may have disrupted other trophic relationships in this community by disturbing or ingesting the macroinfauna or meiofauna that consume a large portion of benthic microalgal productivity (Hiatt 1948, Buffan-Dubau \& Carman 2000), although disturbance of infauna should reduce grazing pressure and result in increased benthic microalgal biomass. P. crassipes may have reduced benthic biomass directly by consuming microalgal mats (Hiatt 1948). In addition, bioturbation from $P$. crassipes burrowing activities likely physically disturbed the microalgal mats. Similar responses of microphytobenthos to bioturbation have been documented in a range of soft-bottom habitats, including estuarine marshes (Boyer \& Fong 2005) and streams (Usio \& Townsend 2002). The reduction of food availability below a critical threshold level necessary for $C$. californica growth may partially explain the decrease in snail growth rates in the presence of $P$. crassipes. Bioturbation can also alter physical characteristics and epifaunal and infaunal fitness (Rhoads \& Young 1970, Palmer 1988), but further studies are needed to explore the trophic implications of such modifications, particularly on epifaunal communities on the west coast of the USA. We did not detect any caging artifacts in our study design, nor qualitatively observe marked erosion or sediment deposition 
around our enclosures, but cage alterations of flowmediated effects that may be impacted by bioturbation, including nutrient flux from the sediments and biofilm erosion, should also be considered in future studies.

Pachygrapsus crassipes may have further lowered snail growth rates by increasing snail burial, effectively reducing the amount of time available for Cerithidea californica to forage. C. californica typically grazes on the sediment surface (Whitlatch \& Obrebski 1980), but may have actively burrowed below the sediment surface as a behavioral response to the threat of predation (McCarthy \& Fisher 2000). Prey behavioral modifications by predators have been documented in a wide range of habitats, including marine (Trussell et al. 2004), aquatic (Peacor \& Werner 1997), and terrestrial (Schmitz et al. 1997) ecosystems and often result in a decrease in prey fitness. Alternatively, C. californica may have been passively buried as an indirect consequence of crab burrowing activities. Either mechanism of burial, whether active or passive, resulted in a reduction of the amount of time snails could graze on the sediment surface and likely contributed to lower $C$. californica growth rates in the presence of crabs. It is likely that a combination of these active and passive burial mechanisms reduced snail grazing activities, illustrating that predators can have a range of indirect impacts on prey assemblages.

Though crabs and nutrients exerted several discrete, measurable impacts on snails and microalgae in this ecosystem, each effect acted in concert with others to shape community structure. Previous studies suggested that nutrients can markedly alter microalgal community composition and grazer survival in this and other soft-sediment systems (Pinckney et al. 1995, Armitage \& Fong 2004b). However, Pachygrapsus crassipes introduced a complex of direct and indirect interactions that reduced the relative importance of nutrients, illustrating the importance of evaluating biotic and abiotic interactions simultaneously. The community-level impacts of the biotic and abiotic interactions in this system revealed a level of complexity not readily apparent from a trophic food web. Rather, a web of direct and indirect, trophic and nontrophic interactions shaped this community. Consideration of this more complete range of interactions will facilitate efforts to understand the suites of forces that structure communities.

Acknowledgements. We are indebted to T. Keeney and the US Navy for providing access to the research site, to R. A. Cohen, L. Green, B. Huntington, R. L. Kennison, V. Minnich, D. Reineman, and S. Wang for their tireless assistance in the laboratory and the field, to C. Janousek and M. Vernet for use of their HPLC equipment and expertise, and to R. R. Vance and R. F. Ambrose for advice on experimental design and comments on the manuscript. This project was funded in part by a UC Coastal Environmental Quality Initiative Graduate Fellowship to A.R.A. and a grant from the EPA (No. R827637) to P.F.

\section{LITERATURE CITED}

Ambrose WG Jr (1984) Role of predatory infauna in structuring marine soft-bottom communities. Mar Ecol Prog Ser 17:109-115

Armitage AR, Fong P (2004a) Gastropod colonization of a created coastal wetland: potential influences of habitat suitability and dispersal ability. Restor Ecol 12:391-400

Armitage AR, Fong P (2004b) Upward cascading effects of nutrients: shifts in a benthic microalgal community and a negative herbivore response. Oecologia 139:560-567

Bertness MD (1985) Fiddler crab regulation of Spartina alterniflora production on a New England salt marsh. Ecology 66:1042-1055

Blumenshine SC, Lodge DM, Hodgson JR (2000) Gradient of fish predation alters body size distributions of lake benthos. Ecology 81:374-386

Bonsdorff E, Norkko A, Sandberg E (1995) Structuring zoobenthos: the importance of predation, siphon cropping and physical disturbance. J Exp Mar Biol Ecol 192: 125-144

Bouyoucos GJ (1962) Hydrometer method improved for making particle size analyses of soils. Agron J 54:464-465

Boyer KE, Fong P (2005) Co-occurrence of habitat-modifying invertebrates: effects on structural and functional properties of a created salt marsh. Oecologia 143:619-628

Brotas V, Plante-Cuny MR (1996) Identification and quantification of chlorophyll and carotenoid pigments in marine sediments: a protocol for HPLC analysis. Oceanol Acta 19: 623-634

Buffan-Dubau E, Carman KR (2000) Diel feeding behavior of meiofauna and their relationships with microalgal resources. Limnol Oceanogr 45:381-395

Byers JE (2000) Differential susceptibility to hypoxia aids estuarine invasion. Mar Ecol Prog Ser 203:123-132

Carpenter SR, Kitchell JF, Hodgson JR (1985) Cascading trophic interactions and lake productivity. BioScience 35: $634-639$

Commito JA, Celano EA, Celico HJ, Como S, Johnson CP (2005) Mussels matter: postlarval dispersal dynamics altered by a spatially complex ecosystem engineer. J Exp Mar Biol Ecol 316:133-147

Ferrão-Filho AS, Azevedo SMFO, DeMott WR (2000) Effects of toxic and non-toxic cyanobacteria on the life history of tropical and temperate cladocerans. Freshw Biol 45:1-19

Geddes P, Trexler JC (2003) Uncoupling of omnivore-mediated positive and negative effects on periphyton mats. Oecologia 136:585-595

Hagerthey SE, Defew EC, Paterson DM (2002) Influence of Corophium volutator and Hydrobia ulvae on intertidal benthic diatom assemblages under different nutrient and temperature regimes. Mar Ecol Prog Ser 245:47-59

Hamilton DJ (2000) Direct and indirect effects of predation by common eiders and abiotic disturbance in an intertidal community. Ecol Monogr 70:21-43

Heck KL Jr, Pennock JR, Valentine JF, Coen LD, Sklenar SA (2000) Effects of nutrient enrichment and small predator density on seagrass ecosystems: an experimental assessment. Limnol Oceanogr 45:1041-1057

Hiatt RW (1948) The biology of the lined shore crab, Pachygrapsus crassipes Randall. Pac Sci 2:134-213 
Hobbs NT (1996) Modification of ecosystems by ungulates. J Wildl Manag 60:695-713

Hunt HL, Mullineaux LS (2002) The roles of predation and postlarval transport in recruitment of the soft shell clam (Mya arenaria). Limnol Oceanogr 47:151-164

Kaehler S, Froneman PW (2002) Herbivore-mediated increase in the photosynthetic capacity of marine biofilms: indirect effects of changing microalgal assemblage composition. Mar Ecol Prog Ser 234:15-22

Kuffner IB, Paul VJ (2001) Effects of nitrate, phosphate and iron on the growth of macroalgae and benthic cyanobacteria from Cocos Lagoon, Guam. Mar Ecol Prog Ser 222: $63-72$

Liess A, Hillebrand H (2004) Direct and indirect effects in herbivore-periphyton interactions. Arch Hydrobiol 159: 433-453

Lorenzen CJ (1967) Determination of chlorophyll and pheopigments: spectrophotometric equations. Limnol Oceanogr 12:343-346

McCarthy TM, Fisher WA (2000) Multiple predator-avoidance behaviours of the freshwater snail Physella heterostropha pomila: responses vary with risk. Freshw Biol 44: 387-397

Menge BA (1995) Indirect effects in marine rocky intertidal interaction webs: patterns and importance. Ecol Monogr 65:21-74

Ólafsson EB, Peterson CH, Ambrose WGJ (1994) Does recruitment limitation structure populations and communities of macroinvertebrates in marine soft sediments? The relative significance of pre- and post-settlement processes. Oceanogr Mar Biol Annu Rev 32:65-109

Paine RT (1974) Intertidal community structure: experimental studies on the relationship between a dominant competitor and its principal predator. Oecologia 15:93-120

Palmer MA (1988) Epibenthic predators and marine meiofauna: separating predation, disturbance, and hydrodynamic effects. Ecology 69:1251-1259

Peacor SD, Werner EE (1997) Trait-mediated indirect interactions in a simple aquatic food web. Ecology 78: 1146-1156

Pinckney J, Paerl HW, Fitzpatrick M (1995) Impacts of seasonality and nutrients on microbial mat community structure

Editorial responsibility: Kenneth L. Heck (Contributing Editor), Dauphin Island, Alabama, USA and function. Mar Ecol Prog Ser 123:207-216

Posey $\mathrm{MH}$, Alphin TD, Cahoon L, Lindquist D, Becker ME (1999) Interactive effects of nutrient additions and predation on infaunal communities. Estuaries 22:785-792

Quammen ML (1984) Predation by shorebirds, fish, and crabs on invertebrates in intertidal mudflats: an experimental test. Ecology 65:529-537

Rhoads DC, Young DK (1970) The influence of deposit feeding organisms on sediment stability and community trophic structure. J Mar Res 28:150-178

Schmitz OJ, Beckerman AP, O'Brien KM (1997) Behaviorally mediated trophic cascades: effects of predation risk on food web interactions. Ecology 78:1388-1399

Sousa WP (1993) Size-dependent predation on the salt-marsh snail Cerithidea californica Haldeman. J Exp Mar Biol Ecol 166:19-37

Thrush SE (1999) Complex role of predators in structuring soft-sediment macrobenthic communities: implications of changes in spatial scale for experimental studies. Aust J Ecol 24:344-354

Trussell GC, Ewanchuk PJ, Bertness MD, Silliman BR (2004) Trophic cascades in rocky shore tide pools: distinguishing lethal and nonlethal effects. Oecologia 139:427-432

Usio N, Townsend CR (2002) Functional significance of crayfish in stream food webs: roles of omnivory, substrate heterogeneity and sex. Oikos 98:512-522

Valiela I, McClelland J, Hauxwell J, Behr PJ, Hersh D, Foreman K (1997) Macroalgal blooms in shallow estuaries: controls and ecophysiological and ecosystem consequences. Limnol Oceanogr 42:1105-1118

Whitlatch RB, Obrebski S (1980) Feeding selectivity and coexistence in two deposit feeding gastropods. Mar Biol 58:219-226

Widbom B, Elmgren R (1988) Response of benthic meiofauna to nutrient enrichment of experimental marine ecosystems. Mar Ecol Prog Ser 42:257-268

Wiltse WI, Foreman KH, Teal JT, Valiela I (1984) Effects of predators and food resources on the macrobenthos of salt marsh creeks. J Mar Res 42:923-942

Wiltshire KH (2000) Algae and associated pigments of intertidal sediments, new observations and methods. Limnologica 30:205-214

Submitted: March 4, 2005; Accepted: October 4, 2005 Proofs received from author(s): March 31, 2006 